DOI 10.37882/2223-2982.2020.04.12

\title{
ПРОГНОСТИЧЕСКИЕ ФАКТОРЫ ПОПЫТОК САМОУБИЙСТВА У ПОДРОСТКОВ С МЫСЛЯМИ О СУИЦИДЕ И АУТОАГРЕССИВНОМ ПОВЕДЕНИИ
}

\section{PROGNOSTIC FACTORS OF SUICIDE ATTEMPTS IN ADOLESCENTS WITH THOUGHTS OF SUICIDE AND SELF- INJURIOUS BEHAVIOR}

E. Isagulova A. Alyohin

Summary: Although suicide is the second leading cause of death among young people in most industrial countries, suicidal behaviour non-fatal is a very important public health problem among adolescents. It is connected primarily with the fact that suicidal thoughts and Neuillyharm is highly correlated with suicide attempts.

Methodology of the study. The study involved 50 young people 21 years who have aged 14-16 years were present with suicidal thoughts (20) or fixed campbridge behavior (30).

The results of the study. $3(15 \%)$ of 20 participants with suicidal thoughts, and 4 patients (13.3\%) of 30 participants with Neuilly campbridge behavior said about making a suicide attempt. Significant factors predicting the risk of suicide attempts in participants with suicidal thoughts are not leading to suicide-harm $(p=0,059)$, drug use $(p=0,029)$, the use of other illicit substances $(p=0,045)$, being in an environment with people campbridge behavior (the family $p=0,076$; friends $-p=0,081)$ and personality types with high intelligence and openness to experience $(p=0,025)$. Among the participants with Neuilly campbridge behavior significant factors of forecasting are the use of drugs $(p=0,038)$, the use of other illicit substances $(p=0,025)$.

The majority of adolescents with suicidal thoughts or campbridge behavior do not commit suicide attempts throughout their life. In the groups with high risk was not detected between suicide attempts and the many factors traditionally considered risk factors for this phenomenon. The results of this study show that conduct population surveys on the use of prohibited substances, the Commission of Neuilly of self-harm and being in an environment with self-harm can help clinicians, psychologists and sociologists in the identification of individuals with a high risk of committing suicide in the future.

Keywords: adolescence, self-injurious behavior, suicidal behavior, suicide, suicide.

\author{
Исагулова Елена Юрьевна \\ Соискатель, ФГБУ ВО «Российский государственный \\ педагогический университет им. А. И. Герцена»; \\ клинический психолог \\ 9477877@gmail.com
}

Алёхин Анатолий Николаевич

Д.м.н., профессор, ФГБУВО «Российский государственный педагогический университет им. А. И. Герцена»

Аннотация: Хотя самоубийство является второй по значимости причиной смерти среди молодежи в большинстве индустриальных стран, суицидальное поведение без смертельного исхода также является очень важной проблемой общественного здравоохранения среди подростков. Это связано в первую очередь с тем, что суицидальные мысли и несуицидальное самоповреждение в значительной мере связаны с попытками самоубийства.

Методика исследования. В исследовании приняли участие 50 молодых людей 21 лет, у которых в возрасте 14-16 лет присутствовали мысли о суициде (20 человек) или зафиксировано самоповреждающее поведение (30 человек). Результаты исследования. 3 (15\%) из 20 участников с суицидальными мыслями и 4 (13,3\%) из 30 участников с несуицидальным самоповреждающим поведением сообщили о совершенной попытке суицида. Значимыми факторами прогнозирования риска попыток самоубийства у участников с суицидальными мыслями являются не ведущее к суициду самоповреждение $(p=0,059)$, употребление наркотиков $(p=0,029)$, употребление иных незаконных веществ $(p=0,045)$, нахождение в среде с людьми с самоповреждающим поведением (семья - $p=0,076$; друзья $-p=0,081$ ) и типы личности с высоким интеллектом и открытостью опыту $(p=0,025)$. Среди участников $c$ несуицидальным самоповреждающим поведением значимыми факторами прогнозирования являются употребление наркотиков $(p=0,038)$, употребление иных незаконных веществ $(p=0,025)$.

Большинство подростков с суицидальными мыслями или самоповреждающим поведением не совершают попыток суицида в течение всей жизни. В исследуемых группах с высоким риском не было обнаружено зависимости между попытками суицида и многими факторами, традиционно считающимися факторами риска данного феномена. Результаты данного исследования показывают, что проведение опросов населения об использовании запрещенных веществ, совершении несуицидальных самоповреждений и нахождении в среде с самоповреждениями может помочь врачам, психологам и социологам в выявлении лиц с высоким риском совершения самоубийства в будущем.

Ключевые слова: подростковый возраст, аутоагрессивное поведение, суицидальное поведение, суицид, самоубийство.

\section{Введение.}

уицидальное и парасуицидальное поведение являются общепризнанными проблемами общества. Около миллиона человек во всем мире совершают самоубийства каждый год. Учитывая, что данные статистики говорят о явных случаях самоубийств, реальный уровень самоубийств может быть в 2-3 раза выше [1]. Данные статистики свидетельствуют о том, что несовершеннолетние представляют наибольшую группу риска 
самоубийства. Было установлено, что одним из самых сильных предикторов завершенного самоубийства или дальнейшей попытки самоубийства является предыдущая попытка самоубийства. Но не более 1/3 подростков с суицидальными мыслями решаются на реальную попытку самоубийства [3].

Согласно результатам многоцентрового исследования, проведенного среди молодых людей в возрасте от 15 до 24 лет, увеличение числа самоубийств среди молодежи связано с увеличением числа попыток самоубийства [16]. Результаты систематического обзора 128 исследований распространенности суицидальных явлений у подростков показали, что в среднем 9,7\% (95\% ДИ от 8,5 до 10,9) подростков сообщали о попытках самоубийства, в то время как даже 29,9\% (95\% ДИ от 26,1 до 33,8$)$ из этих подростков указали, что они думали о самоубийстве в какой-то момент своей жизни [6]. Суицидальные мысли являются довольно распространенным явлением среди подростков и коррелируют с другими показателями психологического стресса.

Факторы риска суицидального поведения подразделяются на топические (острые) и хронические суицидальные риски. В сочетании с острыми факторами риска, например, стресс из-за прекращения отношений, хронические факторы риска, такие, например, как психические расстройства, значительно повышают вероятность суицидального поведения [4]. Кроме того, предлагается разделить факторы риска на факторы-предшественники (например, симптомы депрессии в сочетании с чувством обиды, безнадежности, одиночество, гнев) и потенциальные (например, семейная дисгармония и дисгармония личности) [5]. По мнению американских психологов, опасность и риск самоубийства в значительной степени связаны с использованием Интернета: те, кто играет в видеоигры или проводят в Интернете более чем 5 часов в день могут подвергаться риску развития депрессии и появлению суицидальных мыслей. В частности, тревогу вызывает использование Интернета подростками с суицидальными мыслями для поиска информации, связанной с суицидом. Такие поиски стимулируют суицидальное поведение с высокой вероятностью завершения самоубийства [12]. Социальные и этнопсихологические факторы также относятся к факторам суицидального риска. Среди социальных факторов суицидального поведения выделяют семейные факторы (в частности, психические проблемы со здоровьем, семейная история суицидального поведения, отношения, привязанность и конфликты) и отношения со сверстниками (включая акты запугивания) [3].

Такие факторы, как семейное и сексуальное насилие, пренебрежение потребностями ребенка, а также отношениями с родителями часто встречаются в ситуациях, когда наблюдается суицидальное поведение подрост- ков. Кроме того, потеря родителя в результате смерти или развода, или проживание отдельно от одного или обоих биологических родителей является существенным фактором риска суицида [3]. Некоторые проявления суицидального поведения были достоверно связаны с низким уровнем удовлетворенности семейными отношениями, низкой эмоциональной поддержкой отца и матери, авторитарно-репрессивным стилем отцовского воспитания и снисходительно-пренебрежительным стилем материнского воспитания [10]. Мощным фактором суицидального риска является родительская история попытки самоубийства, что свидетельствует о почти пятикратном увеличении вероятности попытки самоубийства у детей. Поведенческие факторы риска суицида включают личностные и индивидуальные различия, когнитивные факторы, социальные аспекты и негативные жизненные события; факторы идентичности (особенно гендерная идентичность, гендерные и сексуальные предпочтения). Существует влияние сексуальной ориентации на суицидальные мысли. Этот эффект опосредован самоубийством молодежи с факторами риска, включающими депрессию, безнадежность, злоупотребление алкоголем, недавние попытки самоубийства со стороны сверстника или членов семьи, переживания виктимизации [9].

Несмотря на то, что мысли о самоубийстве и самоповреждения, не приведшие к летальному исходу, являются значимым прогностическим параметром попыток самоубийства у подростков, до сих пор мало изученными остаются факторы, обусловливающие эти попытки в группах подростков высокого риска. Получение представлений об этих факторах является крайне важным для точного прогнозирования и предотвращения попыток самоубийства в группах риска подросткового возраста. Большинство научных работ и теорий о вероятности перехода к суицидальным действиям сконцентрированы на изучении и описании суицидальных мыслей [2]. Так, теоретические модели суицидального поведения, такие как интерперсональная теория, интегративная мотивационно-волевая модель, трехшаговая теория содержат в своей основе подход «от мысли к действию», который предполагает различие факторов развития мыслей о самоубийстве и факторов, способствующих переходу от мыслей к действиям. Согласно данным литературы, существует устойчивая корреляция между попытками самоубийства у подростков и суицидальными мыслями, отчаянием, а также частотой и определенными способами самоповреждения [13]. Что касается суицидальных мыслей, многие часто цитируемые факторы риска суицида не выявили значимого различия между суицидальным и несуицидальным самоповреждающим поведением. Единственное проведенное ранее исследование [11] подтверждает значимость параметра частоты самоповреждений для прогнозирования суицидального поведения у подростков с несуицидальным 
самоповреждающим поведением. Авторы показали, что прогностическими факторами являются, в том числе, наличие недостаточного количества социальных связей и отсутствие смысла жизни, а также предыдущие обращения по поводу лечения психиатрических заболеваний. Используемый в исследовании метод, однако, накладывает ограничения на применимость результатов: авторы проводили единовременное обследование группы участников на основе ретроспективных отчётов о факторах риска и попытках суицида. Собранные таким образом данные могут быть неточны из-за ошибок воспоминания участников и того, являются ли описываемые ими ощущения воспоминаниями или планами на будущее.

Лонгитюдных исследований на данную тему, использующих подход «от мысли к действию» крайне мало [7; 8]. В связи с этим в задачи настоящего исследования входит расширение сферы исследования первичных попыток суицида у подростков с суицидальными мыслями и несуицидальным самоповреждающим поведением путём изучения зависимости этого феномена от многочисленных факторов риска в долгосрочной перспективе.

\section{Шель исследования}

Целью настоящего исследования является выявление прогностических факторов попыток самоубийства в подростковой группе высокого риска попыток самоубийства.

\section{Методики и организашия исследования.}

Нами было проведено исследование на базе РГПУ им. А.И. Герцена, в исследовании приняли участие 50 молодых людей, у которых в возрасте 14-16 лет присутствовали мысли о суициде (20 человек) или зафиксировано самоповреждающее поведение (30 человек). Для выявления зависимости между попытками самоубийства и факторами риска был использован метод регрессионного анализа. Первая выборка (20 человек) состояла из подростков, которые ранее сообщили о наличии у них суицидальных мыслей, отвечая на вопрос «Думал ли ты когда-нибудь о самоубийстве, даже если знаешь, что никогда этого не сделаешь?». Вторая выборка включала 30 подростков с несуицидальными самоповреждениями, которые отбирались при помощи ответа на вопрос «Случалось ли тебе наносить себе какой-нибудь вред специально (например, путём передозировки наркотиков, нанесения порезов)?». На момент исследования всем респондентам исполнился 21 год. Критерием исключения из исследования являлось совершение попытки самоубийства в подростковом возрасте.

Участники были разделены на подгруппы в зависимости от того, совершали ли они попытки самоубийства в возрасте 21 года. Участникам с несуицидальными са- моповреждениями, ответившие «да» на вопрос «случалось ли тебе наносить себе какой-нибудь вред специально?» была задана серия дальнейших вопросов для выявления суицидальных намерений. Классификация «самоповреждение с суицидальными намерениями» присваивалась участникам, которые на вопрос о причинах самоповреждения ответили «я хотел умереть», либо дали утвердительный ответ на вопрос «Случалось ли, что в момент нанесения себе вреда умышленно ты действительно хотел убить себя?». В возрасте 14-16 лет участники с преднамеренными и непреднамеренными попытками суицида были классифицированы таким же образом.

В качестве методик исследования были использованы: анкетирование, Шкала поиска ощущений по Арнетту, Международный набор свойств личности (IPIP), опросник DAWBA. Известно, что факторы риска суицидального поведения включают пол, уровень интеллекта, исполнительную функцию, импульсивность, поиск острых ощущений, личностные особенности, наличие окружающих с самоповреждающим поведением, события из жизни, неблагоприятные обстоятельства в детском возрасте, неудовлетворенность телом, проблемы со сном, психические расстройства, отчаяние, симптомы депрессии, употребляемые вещества, суицидальные планы и отдельные характеристики несуицидального самоповреждения. Социально-экономический уровень оценивался путём анкетирования матерей и включал информацию о социальном статусе, а также образовании матери.

Для выявления зависимости между попытками самоубийства и факторами риска у молодёжи 21 года был использован метод регрессионного анализа. Был также проведен дополнительный анализ с контролем по параметру секса в детском возрасте и социально-экономического уровня. Иные параметры, потенциально затрудняющие интерпретацию результатов, были исключены из рассмотрения, так как нашей целью было выявление факторов риска перехода к действию (попыткам самоубийства). Анализ проводился на основе расчетных данных от участников, сообщивших о суицидальных мыслях (20 человек) и о несуицидальных самоповреждениях (30 человек) на момент включения в исследование. Для анализа данных мы использовали программу Statistica 13.3 на платформе Windows.

\section{Результаты исследования и их обсужление.}

Только 3 (15\%) из 20 участников с суицидальными мыслями и 4 (13,3\%) из 30 участников с несуицидальным самоповреждающим поведением сообщили о совершенной попытке суицида. Большинство из них были женского пола и имели родителей с более низким уровнем образования и финансового достатка. Демографические 
данные по группам участников содержатся в таблице 1.

Влияние факторов риска на последующие попытки самоубийства в группе с суицидальными мыслями представлено в таблице 2. Первоначальный анализ показал, что наиболее сильно на переход к попыткам самоубийства в группе с суицидальными мыслями влияют употребление наркотиков $(p=0,029)$ и несуицидальные самоповреждения $(p=0,006)$. Была также обнаружена связь попыток самоубийства с фактором нахождения в среде с другими членами, практикующими самоповреждение (члены семьи $-p=0,076$, друзья $-p=0,081$ ).

Влияние факторов риска на последующие попытки самоубийства в группе с несуицидальными самоповреждениями представлено в таблице 3.

Анализ данных показал, что наиболее сильно на переход к попыткам самоубийства в группе с несуицидальными самоповреждениями влияют употребление наркотиков $(p=0,038)$ и употребление иных незаконных препаратов $(p=0,025)$.

Итак, в ходе работы было выделено несколько факторов, наличие которых позволяет предположить определенный риск попыток самоубийства в указанных группах. У участников исследования в возрасте 14-16 лет риск совершения попытки самоубийства был связан с историей не ведущих к суициду самоповреждений, употреблением наркотиков и других иных незаконных веществ, типами личности с высоким интеллектом и открытостью опыту и нахождение в среде с самоповреждающим поведением. Употребление наркотиков и иных запрещенных законом веществ являются прогностическими факторами перехода к суицидальным действиям у участников с несуицидальным самоповреждением.

Выявление значимых показателей в подгруппе участников с суицидальными мыслями и несуицидальными самоповреждениями представило сложности, однако употребление запрещенных законом веществ и употребление наркотиков, выделенные в обеих выборках, позволяют предположить особую надёжность этих показателей для определения уровня риска совершения попыток самоубийства в будущем. Возможно, употребление наркотиков и других запрещенных законом веществ повышают возможность перехода к суицидальным действиям по причине того, что вызывают снятие внутренних запретов и нарушают способность к принятию адекватных решений. Вероятно, что употребление наркотических веществ со временем ведет к развитию психических заболеваний, которые, в свою очередь, являются причинами самоубийств. С другой стороны, употребление наркотиков может мешать формированию нормального копинг-поведения в ответ на стресс. Можно предположить, что зависимость между самоповреждающим поведением и употреблением наркотиков

Таблица 1

Описание демографических данных выборки

\begin{tabular}{|c|c|c|c|c|c|c|c|c|}
\hline \multirow[t]{3}{*}{ Показатель } & \multicolumn{4}{|c|}{ Группа 1 (20 чел.) } & \multicolumn{4}{|c|}{ Группа 2 (30 чел.) } \\
\hline & \multicolumn{2}{|c|}{$\begin{array}{l}\text { Нет перехода к попыткам са- } \\
\text { моубийства (17 чел.) }\end{array}$} & \multicolumn{2}{|c|}{$\begin{array}{l}\text { Переход к попыткам само- } \\
\text { убийства (3 чел.) }\end{array}$} & \multicolumn{2}{|c|}{$\begin{array}{l}\text { Нет перехода к попыткам } \\
\text { самоубийства ( } 26 \text { чел.) }\end{array}$} & \multicolumn{2}{|c|}{$\begin{array}{l}\text { Переход к попыткам само- } \\
\text { убийства (4 чел.) }\end{array}$} \\
\hline & Кол-во & $\%$ & Кол-во & $\%$ & Кол-во & $\%$ & Кол-во & $\%$ \\
\hline \multicolumn{9}{|l|}{ Пол ребёнка } \\
\hline Мужской & 4 & 23,5 & 0 & 0 & 10 & 38,4 & 1 & 25,0 \\
\hline Женский & 13 & 76,5 & 3 & 100,0 & 16 & 61,6 & 3 & 75,0 \\
\hline \multicolumn{9}{|l|}{ 0бразование матери } \\
\hline Общее среднее & 11 & 65,7 & 2 & 66,7 & 8 & 30,7 & 2 & 50,0 \\
\hline Среднее специальное & 5 & 29,4 & 1 & 33,3 & 10 & 38,5 & 2 & 50,0 \\
\hline Высшее & 1 & 5,9 & 0 & 0 & 8 & 30,8 & 0 & 0 \\
\hline \multicolumn{9}{|c|}{ Социальный класс родителей } \\
\hline Рабочий & 7 & 41,18 & 1 & 33,3 & 5 & 19,2 & 1 & 25,0 \\
\hline Предприниматель & 1 & 5,9 & 0 & 0 & 4 & 15,4 & 1 & 25,0 \\
\hline Госслужащий & 1 & 5,9 & 0 & 0 & 4 & 15,4 & 0 & 0 \\
\hline Безработный & 4 & 23,5 & 2 & 66,7 & 7 & 26,9 & 2 & 50,0 \\
\hline Другое & 4 & 23,5 & 0 & 0 & 6 & 23,1 & 0 & 0 \\
\hline
\end{tabular}


является двунаправленной - взрослые употребляющие наркотики люди часто демонстрировали самоповреждающее поведение в подростковом возрасте. Проведенные ранее исследования указывают, что несуицидальное самоповреждающее поведение является надежным прогностическим фактором попыток самоубийства [15], однако такое поведение редко рассматривается в рамках подхода «от мысли к действию». В нашей работе мы рассмотрели именно этот подход и показали зависимость перехода от суицидальных мыслей к действиям

Таблица 2

Предикторы первичных попыток самоубийства в группе с суицидальными мыслями

\begin{tabular}{|c|c|c|c|c|}
\hline Параметр & $\begin{array}{l}\text { По всей выборке (20 } \\
\text { чел.) }\end{array}$ & $\begin{array}{l}\text { Нет перехода к попыт- } \\
\text { кам самоубийства (17 } \\
\text { чел.) }\end{array}$ & $\begin{array}{l}\text { Переход к попыткам } \\
\text { самоубийства (3 чел.) }\end{array}$ & $\begin{array}{l}\text { Значение вероятности } \\
\text { (р-значение) }\end{array}$ \\
\hline \multicolumn{5}{|l|}{ Пол } \\
\hline Муж & $20 \%$ & $23,5 \%$ & 0 & \\
\hline Жен & $80 \%$ & $76,5 \%$ & $100,0 \%$ & \\
\hline \multicolumn{5}{|l|}{ Психологические параметры } \\
\hline Импульсивность & $13,9 \pm 2,81$ & $14,0 \pm 2,23$ & $13,4 \pm 3,03$ & 0,228 \\
\hline \multicolumn{5}{|l|}{ Поиск острых ощущений } \\
\hline Интенсивность ощущений по Арнетту & $26,0 \pm 4,76$ & $25,9 \pm 4,73$ & $26,5 \pm 4,9$ & 0,29 \\
\hline Новизна ощущений по Арнетту & $26,1 \pm 4,5$ & $26,0 \pm 4,51$ & $26,8 \pm 4,34$ & 0,201 \\
\hline \multicolumn{5}{|l|}{ Измерения личности } \\
\hline Экстраверсия & $33,2 \pm 7,81$ & $33,2 \pm 7,93$ & $33,2 \pm 7,18$ & 0,992 \\
\hline Доброжелательность & $39,3 \pm 4,91$ & $39,3 \pm 4,92$ & $39,5 \pm 4,87$ & 0,693 \\
\hline Добросовестность & $31,2 \pm 5,93$ & $31,3 \pm 5,88$ & $30,8 \pm 6,19$ & 0,639 \\
\hline Эмоциональная стабильность & $28,0 \pm 6,44$ & $28,1 \pm 6,44$ & $27,5 \pm 6,4$ & 0,657 \\
\hline Интеллект / открытость опыту & $36,8 \pm 5,62$ & $36,5 \pm 5,58$ & $38,5 \pm 5,52$ & 0,025 \\
\hline Самоповреждение в семье & $15 \%$ & $5,9 \%$ & $66,7 \%$ & 0,076 \\
\hline Самоповреждение у друзей & $55 \%$ & $52,9 \%$ & $66,7 \%$ & 0,081 \\
\hline \multicolumn{5}{|l|}{ Параметры психического здоровья } \\
\hline $\begin{array}{l}\text { Любой диагноз по оценке развития и бла- } \\
\text { гополучия (DAWBA) }\end{array}$ & $15 \%$ & $11,8 \%$ & $33,3 \%$ & 0,844 \\
\hline Отчаяние & $45 \%$ & $41,2 \%$ & $66,7 \%$ & 0,137 \\
\hline Симптомы депрессии & $11,1 \pm 6,25$ & $11,1 \pm 6,19$ & $11,5 \pm 6,62$ & 0,754 \\
\hline \multicolumn{5}{|l|}{ Употребляемые вещества } \\
\hline Алкоголь, ежедневное опьянение & $25 \%$ & $23,6 \%$ & $33,3 \%$ & 0,830 \\
\hline $\begin{array}{l}\text { Наркотики, в т.ч. эпизодическое приме- } \\
\text { нение }\end{array}$ & $15 \%$ & $11,8 \%$ & $33,3 \%$ & 0,029 \\
\hline Курение, в т.ч. раз в неделю & $25 \%$ & $29,4 \%$ & $33,3 \%$ & 0,333 \\
\hline $\begin{array}{l}\text { Иные запрещенные вещества, за про- } \\
\text { шедший год }\end{array}$ & $15 \%$ & $11,8 \%$ & $33,3 \%$ & 0,029 \\
\hline Суицидальные планы & $10 \%$ & $5,9 \%$ & $33,3 \%$ & 0,800 \\
\hline Несуицидальное самоповреждение & $40 \%$ & $35,9 \%$ & $66,7 \%$ & 0,006 \\
\hline \multicolumn{5}{|c|}{ Частота (только случаи несуицидального самоповреждения) } \\
\hline $1-5$ раз & $25 \%$ & $23,5 \%$ & $33,3 \%$ & \\
\hline$\geq 6$ pa3 & $20 \%$ & $17,6 \%$ & $33,3 \%$ & \\
\hline
\end{tabular}


Таблица 3

Предикторы первичных попыток самоубийства в группе с несуицидальными самоповреждениями

\begin{tabular}{|c|c|c|c|c|}
\hline Параметр & $\begin{array}{l}\text { По всей выборке (30 } \\
\text { чел.) }\end{array}$ & $\begin{array}{l}\text { Нет перехода к попыт- } \\
\text { кам самоубийства ( } 26 \\
\text { чел.) }\end{array}$ & $\begin{array}{l}\text { Переход к попыткам } \\
\text { самоубийства (4 чел.) }\end{array}$ & $\begin{array}{l}\text { Значение вероятности } \\
\text { (р-значение) }\end{array}$ \\
\hline \multicolumn{5}{|l|}{ Пол } \\
\hline Муж & $36,7 \%$ & $38,4 \%$ & $25 \%$ & \\
\hline Жен & $63,3 \%$ & $61,6 \%$ & $75 \%$ & \\
\hline \multicolumn{5}{|l|}{ Психологические параметры } \\
\hline Импульсивность & $13,7 \pm 2,59$ & $13,8 \pm 2,54$ & $13,5 \pm 2,81$ & 0,670 \\
\hline \multicolumn{5}{|l|}{ Поиск острых ощущений } \\
\hline Интенсивность ощущений по Арнетту & $26,2 \pm 4,81$ & $26,2 \pm 4,78$ & $26,2 \pm 4,97$ & 0,848 \\
\hline Новизна ощущений по Арнетту & $26,6 \pm 4,35$ & $26,6 \pm 4,3$ & $26,9 \pm 4,66$ & 0,711 \\
\hline \multicolumn{5}{|l|}{ Измерения личности } \\
\hline Экстраверсия & $35,3 \pm 6,99$ & $35,6 \pm 6,83$ & $33,4 \pm 7,53$ & 0,068 \\
\hline Доброжелательность & $39,1 \pm 4,89$ & $39,1 \pm 4,9$ & $39,1 \pm 4,82$ & 0,837 \\
\hline Добросовестность & $30,4 \pm 6,11$ & $30,5 \pm 6,18$ & $30,3 \pm 5,7$ & 0,773 \\
\hline Эмоциональная стабильность & $28,9 \pm 6,52$ & $29,1 \pm 6,49$ & $27,7 \pm 6,52$ & 0,237 \\
\hline Интеллект / открытость опыту & $36,9 \pm 5,83$ & $36,7 \pm 5,83$ & $37,9 \pm 5,73$ & 0,221 \\
\hline Самоповреждение в семье & $20 \%$ & $19,2 \%$ & $25 \%$ & 0,364 \\
\hline Самоповреждение у друзей & $80 \%$ & $70 \%$ & $75 \%$ & 0,936 \\
\hline \multicolumn{5}{|l|}{ Параметры психического здоровья } \\
\hline $\begin{array}{l}\text { Любой диагноз по оценке развития и бла- } \\
\text { гополучия (DAWBA) }\end{array}$ & $10 \%$ & - & - & 0,403 \\
\hline Отчаяние & $20 \%$ & $19,2 \%$ & $25 \%$ & 0,603 \\
\hline Симптомы депрессии & $87 \pm 5,94$ & $87 \pm 5,89$ & $88 \pm 6,27$ & 0,996 \\
\hline \multicolumn{5}{|l|}{ Употребляемые вещества } \\
\hline Алкоголь, ежедневное опьянение & $36,7 \%$ & $38,5 \%$ & $25 \%$ & 0,452 \\
\hline $\begin{array}{l}\text { Наркотики, в т.ч. эпизодическое приме- } \\
\text { нение }\end{array}$ & $16,7 \%$ & $15,3 \%$ & $25 \%$ & 0,038 \\
\hline Курение, в т.ч. раз в неделю & $13,3 \%$ & $11,5 \%$ & $25 \%$ & 0,116 \\
\hline $\begin{array}{l}\text { Иные запрещенные вещества, за про- } \\
\text { шедший год }\end{array}$ & $26,7 \%$ & $23 \%$ & $50 \%$ & 0,025 \\
\hline Суицидальные планы & $13,3 \%$ & $11,5 \%$ & $25 \%$ & 0,215 \\
\hline Несуицидальное самоповреждение & $40 \%$ & $35,9 \%$ & $66,7 \%$ & 0,006 \\
\hline \multicolumn{5}{|c|}{ Частота (только случаи несуицидального самоповреждения) } \\
\hline $1-5$ раз & $26,7 \%$ & $23 \%$ & $50 \%$ & \\
\hline$\geq 6$ pa3 & $73,3 \%$ & $77 \%$ & $50 \%$ & \\
\hline
\end{tabular}

от наличия несуицидального самоповреждающего поведения. Данная зависимость может быть обусловлена несколькими параметрами, среди которых общая нейробиологическая подверженность самоповреждениям, увеличение риска социального отчуждения или психи- ческого заболевания в результате несуицидального самоповреждения, прямой эффект снижения способности противостоять попыткам самоубийства на фоне мыслей о нем [14]. 
В нашей работе мы обнаружили слабые доказательства зависимости попыток суицида от нахождения в среде с самоповреждающим поведением у подростков с суицидальными мыслями и не обнаружили таковых у подростков, самих демонстрирующих самоповреждающее поведение. Возможно, нахождение в среде с самоповреждениями повышает способность к совершению суицида у подростков с суицидальными мыслями за счет повышения предрасположенности и приемлемости самоповреждающего поведения (например, знание о возможности самоповреждающего поведения, его функциональной выгоде и осведомленность о способах самоповреждающего поведения), в то время как подростки с историей несуицидальных попыток самоповреждающего поведения уже обладают определенным уровнем знаний о способах самоповреждающего поведения.

\section{Выводы}

Выявление прогностических факторов перехода от суицидальных мыслей или несуицидальных самоповреждений к попыткам суицида имеет особую важность для прогнозирования и предотвращения подросткового суицида. Существующие исследования предоставляют важную информацию о факторах, дифференцирующих индивидов с суицидальными мыслями или самоповреждениями от тех, кто совершает попытки суицида. Лонгитюдные исследования, в том числе настоящее, изучают возможность перехода к действиям в длительной перспективе. Результаты данного исследования показывают, что проведение опросов населения об использовании запрещенных веществ, несуицидальных самоповреждениях, типах личности и нахождении в среде с самоповреждениями может помочь работникам сферы здравоохранения в выявлении лиц с высоким риском совершения самоубийства в будущем.

\section{ЛИТЕРАТУРА}

1. Банников Г.С. Кризисные состояния у подростков (пресуицидальные маркеры, особенности личности, стратегии кризисной психотерапевтической помощи) [Электронный ресурс] / Г.С. Банников, К.А. Кошкин // Медицинская психология в России: электрон. науч. журн., 2013. - № 2 (19). - URL: http:// medpsy.ru.

2. Бруг А.В. Клинико-психологическое исследование подростков с рецидивами суицидных попыток: дис. ... канд. мед. наук СПб., 2008. - 176 с.

3. Вагин Ю.Р. Корни суицидальной активности // Суицидология. - 2011. - № 4. - С. 32-48.

4. Попов Ю.В., Пичиков А.А. Суицидальное поведение у подростков, СПб.: СпецЛит, 2017. - 366 с.

5. Asarnow J.R., Porta G., Spirito A. Suicide attempts and nonsuicidal self-injury in the treatment of resistant depression in adolescents: findings from the TORDIA study // J Am Acad Child Adolesc Psychiatry. 2011, № 50, p. 772-781.

6. Borschmann R., Becker D., Coffey C. 20-year outcomes in adolescents who self-harm: a population-based cohort study // Lancet Child Adolesc Health. 2017, № 1, p. 195-202.

7. Brent D.A., Melhem N.M., Oquendo M., Burke A., Birmaher B., Stanley B., Porta G. Familial pathways to early-onset suicide attempt: a 56-year prospective study // JAMA psychiatry. 2015. - Vol. 72, № 2, p. 160-168.

8. Burke T.A., Alloy L.B. Moving toward an ideation-to-action framework in suicide research: a commentary on May and Klonsky // Clin Psychol. 2016, № 23, p. 26-30.

9. Franklin J.C., Ribeiro J.D., Fox K.R., Bentley K.H., Kleiman E.M., Huang X., Nock M.K. Risk factors for suicidal thoughts and behaviors: a meta-analysis of 50 years of research // Psychological Bulletin. 2017. - Vol. 143, № 2, p. 187.

10. Goldman-Mellor S., Caspi A., Harrington H. Suicide attempt in young people: a signal for long-term healthcare and social needs // JAMA Psychiatry. 2014, № 71, p. $119-127$.

11. Guan K., Fox K.R., Prinstein M.J. Nonsuicidal self-injury as a time-invariant predictor of adolescent suicide ideation and attempts in a diverse community sample // J Consult Clin Psychol. 2012, № 80, p. 842-49.

12. Hagihara A., Miyazaki S., Abe T. Internet suicide searches and the incidence of suicide in young people in Japan // European archives of psychiatry and clinical neuroscience. 2012. - Vol. 262, № 1, p. 39-46.

13. Hamza C.A., Stewart S.L., Willoughby T. Examining the link between nonsuicidal self-injury and suicidal behavior: a review of the literature and an integrated model // Clin Psychol Rev. 2012, № 32, p. 482-495.

14. Kaess M., Parzer P., Haffner J. Explaining gender differences in non-fatal suicidal behaviour among adolescents: a population-based study // BMC Public Health. 2011, № 11, p. 597-599.

15. Klonsky E.D., Qiu T., Saffer B.Y. Recent advances in differentiating suicide attempters from suicide ideators // Curr Opin Psychiatry. 2017, № 30, p. 15-20.

16. Klonsky E.D., May A.M., Glenn C.R. The relationship between nonsuicidal self-injury and attempted suicide: converging evidence from four samples // J Abnorm Psychol. 2013, № 122, p. 231-37.

17. Mars B, Heron J, Crane C, et al. Clinical and social outcomes of adolescent self harm: population based birth cohort study. BMJ 2014; 349 : g5954.

18. May A.M., Klonsky E.D. What distinguishes suicide attempters from suicide ideators? A meta-analysis of potential factors // Clin Psychol. 2016, № 23, p. 5-20.

19. Messias E., Castro J., Saini A., Usman M., Peeples D. Sadness, suicide, and their association with video game and internet overuse among teens: results from the youth risk behavior survey 2007 and 2009 // Suicide and Life-Threatening Behavior. 2011. - Vol. 41, № 3, p. 307-315. 
20. Moran P., Coffey C., Romaniuk H., Degenhardt L., Borschmann R., Patton G. Substance use in adulthood following adolescent self-harm: a population-based cohort study // Acta Psychiatr Scand. 2015, № 131, p. 61-68.

21. O'Connor R.C., Nock M.K. The psychology of suicidal behavior // The Lancet Psychiatry. 2014. - Vol. 1, № 1, p. 73-85.

22. Van Orden K.A., Witte T.K., Cukrowicz K.C., Braithwaite S.R., Selby E.A., Joiner T.E.Jr. The interpersonal theory of suicide // Psychol Rev. 2010, № 117, p. $575-600$.

23. Victor S.E., Klonsky E.D. Correlates of suicide attempts among self-injurers: a meta-analysis // Clin Psychol Rev. 2014, № 34, p. $282-297$.

24. Whitlock J., Muehlenkamp J., Eckenrode J. Nonsuicidal self-injury as a gateway to suicide in young adults // J Adolesc Health. 2013, № 52, p. 486-492.

25. Wilkinson P., Kelvin R., Roberts C., Dubicka B., Goodyer I. Clinical and psychosocial predictors of suicide attempts and nonsuicidal self-injury in the Adolescent Depression Antidepressants and Psychotherapy Trial (ADAPT) // Am J Psychiatry. 2011, № 168, p. 495-501.

26. Wilkinson P.O., Qiu T., Neufeld S., Jones P.B., Goodyer I.M. Sporadic and recurrent non-suicidal self-injury before age 14 and incident onset of psychiatric disorders by 17 years: prospective cohort study // Br J Psychiatry. 2018, № 212, p. 222-226.

27. Zimmerman G.M., Rees C., Posick C., Zimmerman L.A. The power of (Mis) perception: Rethinking suicide contagion in youth friendship networks // Social Science \& Medicine. 2016, № 157, p. 31-38.

(с) Исагулова Елена Юрьевна (9477877@gmail.com), Алёхин Анатолий Николаевич.

Журнал «Современная наука: актуальные проблемы теории и практики»

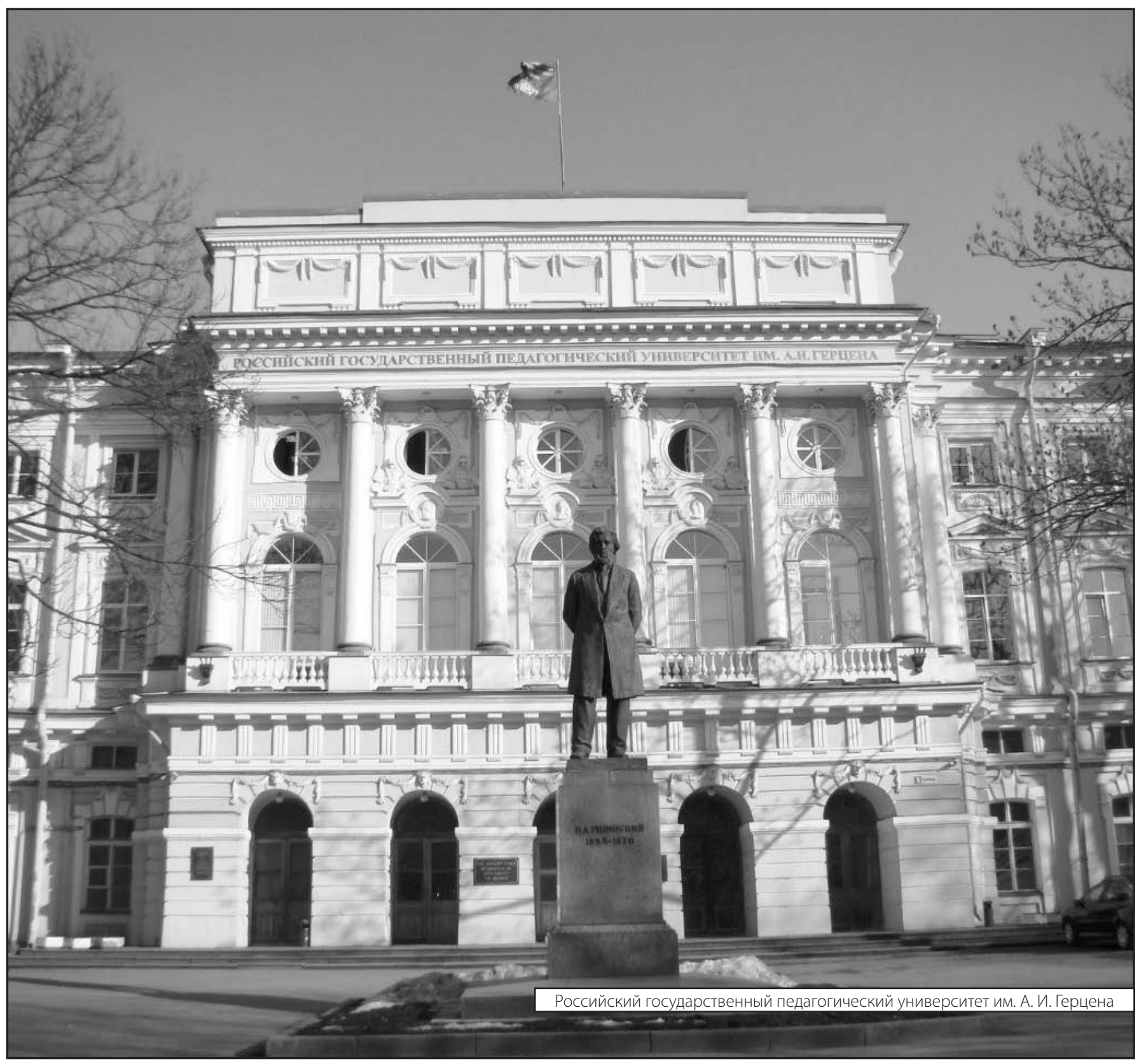

